\title{
Vocational Education in the Industrial 4.0 Era:
}

\author{
Challenges and Opportunities
}

\author{
Aam Hamdani*, Aim Abdulkarim, Diah Cahyani P, Eki Nugraha \\ Universitas Pendidikan Indonesia \\ Bandung, Indonesia \\ *aam_hamdani@upi.edu
}

\begin{abstract}
This resonance of the Industrial Revolution 4.0 has been predicted to peak since the 2000s, when technology and information innovation experienced rapid development. Industry 4.0 has a very large and broad impact, especially in the employment sector, where robots and machines will eliminate many jobs in the world. This of course must have been anticipated by vocational education that is able to answer these challenges. The purpose of this research is to get the formulation of the revitalization of vocational education in Indonesia in order to form the skills competencies needed in the era of the industrial revolution 4.0. This research uses participatory qualitative research methods. Data obtained through literature studies, interviews and discussions (FGD). The results of the study show that vocational education is a program to support the realization of smart education through increasing and equalizing the quality of education, expanding access, and the relevance of utilizing technology in realizing skill competencies in the industrial era 4.0. The revitalization of vocational education is aimed to producing students who have four competencies, namely critical thinking (Cricical Thinking), collaboration, communication, and creativity.
\end{abstract}

Keywords-industrial revolution 4.0, vocational education, critical thinking, collaboration, communication, creativity

\section{INTRODUCTION}

Currently, the world is faced with job disruption in several industrial lines. The demand for individual competences with the mastery of new competencies is a necessity for every company. Previously, competencies such as in the field of big data specialists, artificial intelligence (AI) specialists, or data analysis had not yet been needed. However, from the last few years to the next decades, the demand for workers with competency in this sector is predicted increased significantly. However, from the last few years to the next decades, the demand for workers with competence in this sector is predicted to skyrocket. Industry 4.0 (fourth industrial revolution) summarizes the future development trends of industry to achieve smarter manufacturing processes, including reliance on Cyber-Physical Systems (CPS), development of Cyber Physical Production Systems (CPPS), and implementation and operation of smart factories. These aspects are relevant from Industry 4.0 in relation to strategic planning, key technologies, opportunities, and challenges [1].
The white paper published by the World Economic Forum (WEF) in January 2020, the world currently needs the Education 4.0 method to support The 4.0 Industrial Revolution. It can also change the way of education view. The changes made are not just a way of teaching, but more essential, a change in perspective on the concept of education itself. According to Sukartono, education at least must be able to prepare students to face three things: a) to work for which jobs do not currently exist [2]; b) to be able to solve problems whose problems have not yet appeared, and c) to be able to use technology whose technology has not yet been found.

In the industrial 4.0 era, vocational education must be able to develop new creations and innovations. As a policy maker, the government is expected to review the balance between vocational education and employment to face changes, opportunities and challenges in this era while still paying attention to human aspects. A set of attributes, skills and knowledge that all labour market participants should possess to ensure they have the capability of being effective in the workplace - to the benefit of themselves, their employer and the wider economy [3]. According to Puriwat that Education 4.0 has transformed globalization to the innovation's education, the main purpose of this education era is to produce graduates which much higher skills on innovation and digital technology than before. It weighs on the creative and innovative thinking skills to drive and cross over the poverty of nation for becoming the prosperity and sustainability of economy and society [4].

There are opportunities and challenges in the industrial era 4.0, vocational education must be able to develop new creations and innovations. As a policy maker, the government is expected to review the balance between vocational education and employment to face changes, opportunities and challenges in this era while still paying attention to human aspects. Of course, the challenges for vocational education will be increasingly complex with the presence of industry 4.0. This paper discusses and explores the characters and abilities that high school / vocational school and university graduates need to have in order to compete in the era of the industrial revolution 4.0. The impact of this research is to provide input to policy holders for the revitalization of vocational education 
in Indonesia in order to form the skills competencies needed in the era of the industrial revolution 4.0.

\section{MethOD}

This research uses participatory qualitative research methods. Data obtained through literature studies, interviews and discussions (FGD). Interviews and focus group discussions involving the Bandung City Education Agency, the Manpower Office, and professional certification institutions related to vocational education.

Opinions about vocational education from the three institutions are processed by the triangulation method and adjusted to the results of the literature review.

\section{RESULTS AND DisCUSSION}

In the white paper published by the World Economic Forum (WEF), eight critical characteristics are mentioned in content and learning experiences for implementing Education 4.0. These characteristics include the ability of the global community, to innovate and be creative, technological skills, interpersonal skills, and personalized and self-paced learning. Furthermore, there is inclusive learning, problem-based and collaborative learning, and lifelong and student-driven learning.

Launching Kompas.com, Thursday (16/1/2020), the learning methods of Science, Technology, Engineering, Arts, Mathematics (STEAM) are one of the important keys to the world of education in facing the 4.0 era. The reason is, STEAM can encourage the development of science, technology, engineering and mathematics to be more creative. The five disciplines become one of the comprehensive educational approaches as a pattern of problem solving through the $21 \mathrm{st}$ century learning experience which is one of cooperative learning as part of constructivism learning, where students will build their own knowledge and understanding through projects. The given project requires students to understand the material being studied as knowledge, utilizing developing technology to help find concepts.

P21 (Partnership for $21^{\text {st }}$ Century Learning) develops a learning framework in the $21^{\text {st }}$ century that requires students to have skills, knowledge and abilities in the fields of technology, media and information, learning and innovation skills as well as life and career skills (P21, 2015). This framework also describes the skills, knowledge and expertise that must be mastered so that students can succeed in life and work. Look at the following picture.

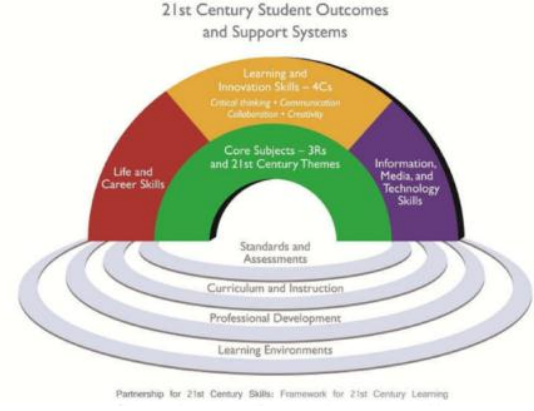

Fig. 1. Learning Framework $21^{\text {st }}$ century.

In line with this, the Ministry of Education and Culture formulates the 21st century learning paradigm emphasizes the ability of students to find out from various sources, formulate problems, think analytically and collaborate in solving problems [5]. The explanation regarding the 21st century learning framework according to BSNP is as follows [6]: (a) Critical-Thinking and Problem-Solving Skills, able to think critically, laterally, and systemically, especially in the context of problem solving; (b) Communication and Collaboration Skills, able to communicate and collaborate effectively with various parties; (c) Creativity and Innovation Skills, able to develop their creativity to produce various innovative breakthroughs; (d) Information and Communications Technology Literacy, able to utilize information and communication technology to improve performance and daily activities; (e) Contextual Learning Skills, being able to undergo contextual independent learning activities as part of personal development, and (f) Information and media literacy skills, being able to understand and use various communication media to convey various ideas and carry out collaborative activities as well as interactions with various parties.

Yahya identifies the challenges of vocational education in the industrial 4.0 era as follows [7]; 1) information technology security issues; 2) reliability and stability of production machines; 3) lack of adequate skills; 4) reluctance to change by stakeholders; and 5) the loss of a lot of work from turning to automation. The emergence of these challenges certainly requires a vocational education system that is able to answer these challenges. In line with identified trends and challenges, a greater focus on high quality and inclusive continuing VET should entail: (a) addressing the whole workforce, including people in employment and the large share of the population currently in the margins or out of the labour market; (b) shifting learning provision from job-specific technical skills to key competences relevant to work that facilitate labour market transitions and enhance learning and career development; (c) creating learning pathways with better integration and coordination between VET and general education, as well as between formal, non-formal and informal training, for lifelong learning to become an operational reality

In addition, one of the efforts that must be made to answer the challenges of Industry 4.0 is to pay attention to the characteristics that must be present in vocational education, 
namely as follows [8];1) emphasizes individual orientation; 2) special assessment is based on what is being needed in the field; 3) psychomotor, affective, and cognitive aspects are the main focus of curriculum development 4) school is not the only place that becomes a measure of one's success; 5) an adequate existing school facilities and infrastructure in schools; and 6) involving counseling teachers as parties to assist students' career planning and community support.

\section{CONCLUSION}

The existing opportunities for the development of education in the industrial 4.0 era, among vocational education must have the following characteristics: Critical-Thinking and ProblemSolving Skills, Communication and Collaboration Skills, Creativity and Innovation Skills, Information and Communications Technology Literacy, and Contextual Learning Skills. Challenges faced by vocational education in the 4.0 era: 1) information technology security issues; 2) reliability and stability of production machines; 3) lack of adequate skills; 4) reluctance to change by stakeholders; and 5) the loss of a lot of work from turning to automation.

\section{ACKNOWLEDGMENTS}

This acknowledgment delivered to the West Java Province Labor and Transmigration Office and the Indonesian Metal Machinery LSP, as a speaker in focus group discussions.
Thanks are also conveyed to the PIU-UPI ADB Manager, because through funds from the ADB AKSI (advanced Knowledge and Skills for Sustainable Growth) project, this research can be carried out well.

\section{REFERENCES}

[1] K. Zhou, T. Liu, and L. Zhou, "Industry 4.0: Towards future industria opportunities and challenges," [In 2015 12th International conference on fuzzy systems and knowledge discovery (FSKD)] pp. 2147-2152, 2015, August. IEEE.

[2] Sukartono, Revolusi Industri 4.0 dan Dampaknya terhadap Pendidikan di Indonesia, FIP PGSD Universitas Muhammadiyah Surakarta, 2018.

[3] T. Griffin, "Challenges and opportunities for VET,National Vocational Education and Training Research Conference," National Centre for Vocational Education Research (NCVER), 2020.

[4] W. Puriwat and S. Tripopsakul, "Preparing for Industry 4.0 -- Will Youths Have Enough Essential Skills?," An Evidence from Thailand, International Journal of Instruction, Vol.13, No.3, pp. 89-104, 2020.

[5] Litbang Kemdikbud, 2013

[6] Badan Nasional Sertifikasi Profesi, 2010.

[7] M. Yahya, Era Industri 4.0: Tantangan Dan Peluang Perkembangan Pendidikan Kejuruan Indonesia. Pidato Pengukuhan Penerimaan Jabatan Professor. https://doi.org/10.1080/15298868.2011.636509, 2018.

[8] Y. Umeda, J. Ota, F. Kojima, M. Saito, H. Matsuzawa, T. Sukekawa and S. Shirafuji, "Development of an education program for digital manufacturing system engineers based on 'Digital Triplet'concept," Procedia manufacturing, 31, pp. 363-369, 2019. 